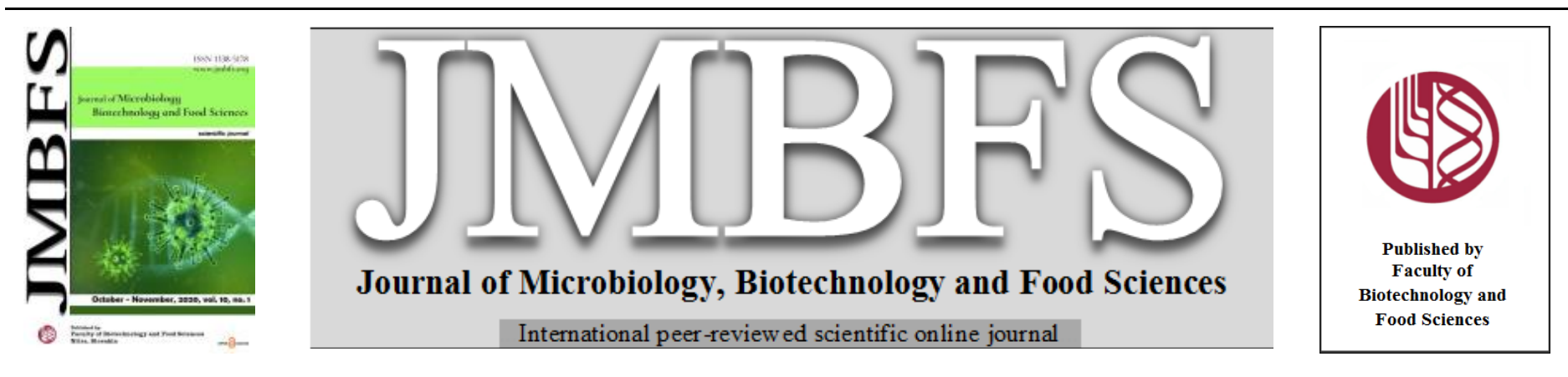

\title{
KINETICS OF ANTIOXIDANTS DEGRADATION AND QUALITY CHANGES OF CITRON (Citrus medica) FRUIT JUICE CONCENTRATE DURING STORAGE
}

\author{
Pappu Dey, Md. Mozammel Hoque, Md. Zohurul Islam*, Kamrunnaher Monalisa
}

Address(es): Md Zohurul Islam,

Department of Food Engineering and Tea Technology, Shahjalal University of Science and Technology, Sylhet-3114, Bangladesh.

*Corresponding author: zohurul-fet@sust.edu

doi: 10.15414/jmbfs.2020.10.2.230-234

\section{ARTICLE INFO}

Received 5. 2. 2020

Revised 17. 6. 2020

Accepted 18. 6. 2020

Published 1. 10. 2020

Regular article

OPEN $\partial_{\text {ACCESS }}$

\begin{abstract}
The aim of the study was to develop fruit juice concentrate from Citron and its kinetic evaluation during storage at $10{ }^{\circ} \mathrm{C}, 25{ }^{\circ} \mathrm{C}$ and 40 ${ }^{\circ} \mathrm{C}$ respectively, for $12^{\text {th }}$ week. The effect of different temperatures on the quality of the juice concentrate was also investigated. The concentration of ascorbic acid in the juice concentrate was monitored after every week of storage. The results showed that degradation kinetics of ascorbic acid during storage was followed by the first-order kinetics. The degradation rates of ascorbic acid during storage at $10^{\circ} \mathrm{C}, 25^{\circ} \mathrm{C}$ and $40^{\circ} \mathrm{C}$ were obtained as $2.27 \pm 0.24,2.46 \pm 0.31$ and $2.56 \pm 0.341$ /week respectively. The higher degradation rate was observed at $40{ }^{\circ} \mathrm{C}$ storage temperature. Temperature-dependent rate constants of ascorbic acid of citron juice concentrate was obeyed the Arrhenius relationship with higher $\mathrm{R}^{2}$ values as 0.96 . Total antioxidant degradation was also high at higher storage temperatures. The amount of total phenolic content was decreasing at the first few weeks of storage, but later period of storage it was in gradually increasing trend. The storage study demonsrated that ascorbic acid, total polyphenol and antioxidant activity were not degraded at lower temperature after $12^{\text {th }}$ week.
\end{abstract}

Keywords: kinetics, degradation, citron juice concentrate, ascorbic acid, storage

\section{INTRODUCTION}

Citrus fruits are native to Southeast Asia. The purest citrus species are Citron (Citrus medica), Mandarin (Citrus reticulata) and Pomelo (Citrus maxima) (Luro et al., 2012). Citrus medica is the botanical name of citron under the family of Rutaceae (Hamdan et al., 2011). The shape of the citron is generally ovate or oblong with a stylar end. Around 9-30 cm long fruits having maximum weight $400-500 \mathrm{~g}$ are rough or plane in the outside. The fully ripe fruits become yellow. The fleshy fruits contain albedo inner side, and pulp are pale-yellow or greenish having 14-15 segments, less juice content, acidic or sour taste. Fruits also contain mono-embryonic seeds. There are three most common cultivars of citrons are 'Corsican', 'Diamante' and 'Etrog.' Among them, Corsican is grown higher in US, Diamante higher in Italy and Etrog higher in Israel. The Florentine, Diamante, Greek and Balady citrons are acidic while the Corsican and Moroccan citrons are sweet in nature and citron contains the major major bioactive compounds present are iso-limonene, citral, limonene, phenolics, flavonones, vitamin C, pectin, linalool, decanal, and nonanal, accounting for several health benefits (Chhikara et al., 2018). Citron is also one of the typical local fruits in the Sylhet region of Bangladesh. The main time for harvesting of citron is the mid-late July to mid-September or mid-October. During November and December, some fruits are also harvested (Klein et al., 2014).

A variety of chemicals were present in citron. Peel contains alkaloids, flavonoids, steroids phenols, and carbohydrates (Panara et al., 2012) and pulp contains flavonoids, glycosides and ascorbic acid (Arias et al., 2005). Citron also contains phenols, vitamin E, beta-carotene and lipotene (Panara et al., 2012). Among these antioxidants, ascorbic acid is an important one. Citrons have a lot of medicinal benefits. It can be used as a poison antidote. To avoid sea sickness, pulmonary troubles and intestinal aliments citron is used from ancient time.

Citrus medica varieties are mainly used in food preservation and have excellent medicinal properties. Metabolic activities in fresh fruit do not stop during storage. As a result, the antioxidant quantities of the fruits degrades. Antioxidant quantities were also reduced due to the thermal effect during the processing of juice (Wilhelmina Kalt et al., 1999). Ascorbic acid one of the important natural antioxidants (Tiwari et al., 2009). The degradation of ascorbic acid in any product mainly depends on storage time and temperature, the expose of oxygen and light in the product. That's why it is important to maintain a standard procedure and temperature for processing and storage of citron juice to provide maximum ascorbic acid content in citron fruit product when consumer uptake this.
Therefore, it is important to develop and use low-level appropriate technology for the processing and preservation of processed Citrus medica products. The aim of our study was to produce fruit juice concentrate from three cultivars of citron (Balady, Diamonte, and Corsican), to find out the kinetics of Ascorbic acid degradation of citron juice concentrate during storage at three different temperatures $\left(10{ }^{\circ} \mathrm{C}, 25{ }^{\circ} \mathrm{C}\right.$ and $\left.40{ }^{\circ} \mathrm{C}\right)$ and to find out the effect of storage temperature and time on the antioxidant and total phenolic content of the juice concentrate.

\section{MATERIALS AND METHODS}

\section{Raw materials}

The fresh matured Balady, Corsican and Diamante citron were collected from a local garden in Sylhet, Bangladesh. Five fruits of each cultivar were collected, and the average weights of them were $400 \mathrm{gm}-450 \mathrm{gm}$. All fruits were mature but not fully ripened. The image of the citron fruits cultivars, as presented in Fig. 1.

\section{Sample Preparation}

Fruits were first washed properly with clean distilled water. The peel of the citron was removed by the steel cutter. Then the white albedo and pulps were sliced into pieces and seeds were removed. The cross-sections of the fruits are shown in Fig. 2. The fruit juices were extracted by laboratory mixture blender (MJ-M176P, Japan). The juice was then filtered and transferred into several test bottles and stored in the freezer at $-30{ }^{\circ} \mathrm{C}$ temperature for further analysis. 


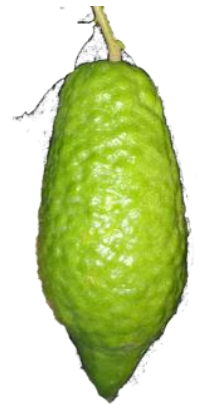

a) Balady

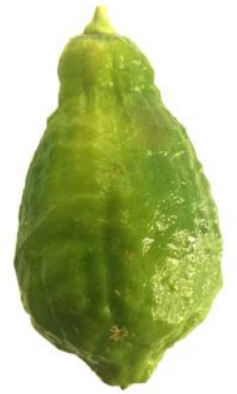

b) Corsican

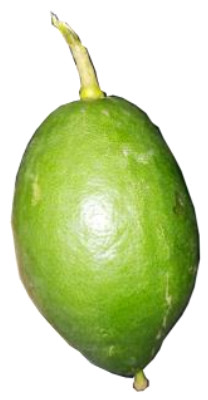

c) Diamante
Figure 1 Citrus medica respectively Balady, Corsican and Diamant

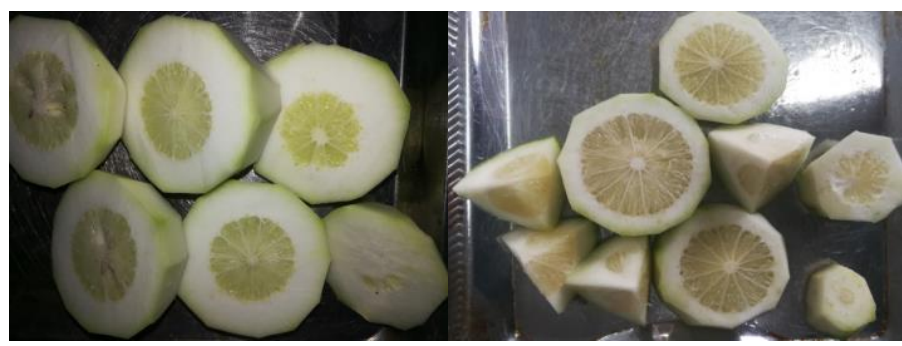

a) Balady

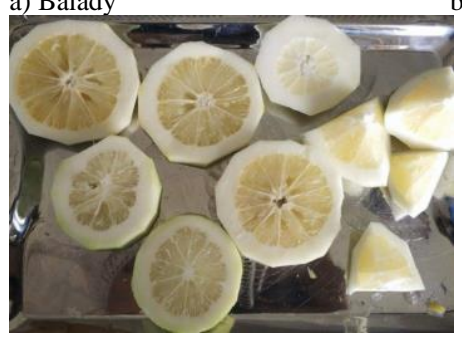

c) Diamante

Figure 2 Cross section of the citrons respectively Balady, Corsican and Diamante variety

\section{Processing of citron juice concentrate}

For making mix fruit juice concentrate, the equal amount of juice of three cultivars was mixed properly to get $1000 \mathrm{~mL}$ of juice. Sugar syrup is one of the most important elements of juice concentrate was made by mixing sugar with clean distilled water in the ratio of 1:2 (sugar : water). The sugar-water mixture was continuously stirred and heat was applied on it until all the sugar was mixed with water. A very small amount of citric acid was added to clarify the syrup (Singh et al., 2015). After that, the syrup was cooled at room temperature $25^{\circ} \mathrm{C}$ and filtered to remove the unwanted foreign materials from the syrup. Then the fruit juice was mixed with that filtered sugar syrup rightly and final Brix was kept at $45^{\circ}$ Brix. The juice concentrates were kept in several sterilized and air-tight glass bottles.

\section{Storage study}

The samples were divided into three groups and stored for twelve weeks at three different temperatures: $10{ }^{\circ} \mathrm{C}, 25{ }^{\circ} \mathrm{C}$ and $40{ }^{\circ} \mathrm{C}$ respectively. The storage evaluation were carried out every week.

\section{Determination of total soluble solids and $\mathrm{pH}$ value}

Total soluble solid was determined as ${ }^{\circ}$ Brix by using a Hand refractometer (ATAGO 9099, Japan). pH of the juice was determined by using digital $\mathrm{pH}$ meter (Microprocessor- based $\mathrm{pH} / \mathrm{mV} /{ }^{\circ} \mathrm{C}$ Bench meter, MN 2211, USA).

\section{Determination of total acidity}

The total acidity of the juice was measured according to Patil et al., (2013). $1 \mathrm{ml}$ of juice was dissolved in $20 \mathrm{ml}$ distilled water. Two drops of Phenolphthalein were added to the mixture. The mixture was then titrated with standardized $\mathrm{NaOH}(0.1 \mathrm{M})$ and the end point was determined by the pink color of the mixture. Following equation was used for the calculation,

Total acidity $(\%)=\frac{0.1 \mathrm{M} \mathrm{NaOH} \times \text { volume of } \mathrm{NaOH}(\text { in liter }) \times 0.064}{\text { wt.of the sample }} \times 100$.

Determination of ascorbic acid content
The ascorbic acid of citron juice concentrate was determined according to the method described by Ranganna (1986) and which was based on the reduction of 2,6-dicholorophenol indophenols by ascorbic acid and based on the reduction of dehydroascorbic acid with 2,4-dinitrophenylhydrazine. The ascorbic acid content of the citron juice concentrate expressed as $\mathrm{mg} / 100 \mathrm{~g}$.

\section{Extract preparation}

The extract of the citron juice concentrates was prepared according to the method described by Islam et al. (2017) and Monalisa, et al. (2019) with slight modifications. We extracted the fruit juice concentrated using $80 \%$ acetone with a ratio of 1:10 (sample : solvent) and a shaking incubator (SI-100, Korea) was used to incubate the mixture at $20{ }^{\circ} \mathrm{C}$ for $90 \mathrm{~min}$. Then the crude extract was centrifuged in a centrifuge machine (Gyrozen Benchtop Centrifuge machine, $416 \mathrm{G}$, Korea) at $3,000 \mathrm{rpm}$ for $15 \mathrm{~min}$.

\section{Determination of total phenolic Content}

Folin-Ciocalteau assay was used to determine the total phenolic content in the sample extracts (Monalisa \& Islam, 2020; Vijaya Kumar Reddy, Sreeramulu, \& Raghunath, 2010). The analysis was done by taking $20 \times 10^{-3}$ $\mathrm{ml}$ of extract in separate test tubes. Then $1.58 \mathrm{ml}$ distilled water and $0.1 \mathrm{ml}$ of Folin-Ciocalteau reagent added in each test tubes. The mixture mixed well and within $8 \mathrm{~min} 0.3 \mathrm{ml}$ of sodium carbonate solution was added in each. Then immediately, the test tubes were vortexed (VM-2000, Taiwan) and incubated for $30 \mathrm{~min}$ at $40{ }^{\circ} \mathrm{C}$ in the dark place. At $765 \mathrm{~nm}$ wavelength the absorbance was measured in a UV-Vis spectrophotometer (T60U, United kingdom). The results were expressed in $\mathrm{mg}$ Gallic acid equivalent (mgGAE/g). The standard gallic acid curve was used for getting the equation of total phenol determination.

\section{Determination of DPPH Activity}

Radical scavenging activity of the sample extracts was measured by determining the inhibition rate of DPPH (2, 2-diphenyl-1-picrylhydrazyl) radical (BrandWilliams, Cuvelier, \& Berset, 1995). Here, $0.1 \mathrm{ml}$ of extracts was added to 1.4 $\mathrm{ml}$ DPPH radical methanolic solution $(0.1 \mathrm{Mm})$. Then the mixture was placed in a dark place for 30 minutes. A blank solution was made by $0.1 \mathrm{ml}$ methanol in 1.4 $\mathrm{ml}$ of DPPH radical solution. The absorbance was measured at $517 \mathrm{~nm}$ wavelength using a UV-Vis Spectrophotometer (T60U, United kingdom). The results were expressed in terms of radical scavenging activity using the following equation.

Radical scavenging activity $(\%)=\frac{\mathrm{A}_{0}-\mathrm{As}}{\mathrm{A}_{0}} \times 100$

Where $A_{o}$ is the absorbance of control blank, and $A_{s}$ is the absorbance of sample extract.

\section{Degradation kinetics modeling}

The loss of ascorbic acid in citron juice concentrate was measured by using firstorder reaction equation given below (Burdurlu, Koca, \& Karadeniz, 2006).

$$
\ln \mathrm{C}=\ln \mathrm{C}_{0}-\mathrm{kt}
$$

where $\mathrm{C}$, the concentration of ascorbic acid at time $\mathrm{t} ; \mathrm{C}_{0}$, the concentration of ascorbic acid at time zero; $\mathrm{k}$, the first-order rate constant; $\mathrm{t}$, the storage time (week).

The time at which the amount of ascorbic acid decreased to half of its initial value refers half time. The following equation was used for half time calculation (Burdurlu et al., 2006).

$$
\mathrm{t}_{1 / 2}=\frac{\ln 2}{\mathrm{k}}
$$

Temperature reliance on ascorbic acid degradation was ascertained by using the Arrhenius equation.

$$
\mathrm{k}=\mathrm{k}_{0} \cdot \mathrm{e}^{-\mathrm{E}_{\mathrm{a}} / \mathrm{RT}}
$$

$\mathrm{k}=$ rate constant; $\mathrm{k}_{0}=$ pre-exponential factor; $\mathrm{E}_{a}=$ activation energy $\left(\mathrm{kj} \mathrm{mol}^{-1}\right)$; $\mathrm{R}=$ gas constant $\left(8.3145 \mathrm{jmol}^{-1} \mathrm{k}^{-1}\right) ; \mathrm{T}=$ absolute temperature in $\mathrm{k}$ (Burdurlu et al., 2006).

Substituting k from (3) to (1), we get,

$$
\ln \frac{\mathrm{C}_{0}}{\mathrm{C}}=\mathrm{k}_{0} \cdot \mathrm{e}^{-\mathrm{E}_{\mathrm{a}} / \mathrm{RT}}
$$

The time required to decrease the concentration of ascorbic acid $90 \%$ is known as the decimal reduction time (D value). There is an inverse relationship between 
the first-order rate constant $\mathrm{k}$ and decimal reduction time $\mathrm{D}$ and that's why equation (1) can be written as,

$$
\ln C_{0}-\ln C=\frac{\mathrm{t}}{\mathrm{D}}
$$

Using the equations (4) and (7), the decimal reduction time D can be described as

$$
\mathrm{D}=2.203 / \mathrm{k}
$$

\section{Statistical analysis}

The measurements were carried out in triplicates and were presented at a mean \pm standard deviation. Statistical analysis was carried out by one-way analysis of variance with Origin pro 8.0 statistical software. The statistically significan difference among the values was determined by considering the probability values of $p \leq 0.05$.

\section{RESULTS AND DISCUSSION}

\section{Physicochemical properties of citron juice concentrate}

All three types of citron juice were used in equal proportion for the formulation of juice concentrates. The physicochemical properties of the citron juice concentrate are presented in Table 1 . In the present study, the total soluble solids (TSS) content of citron juice concentrate was found at the initial stage of 45.00 $0.20^{\circ}$ Brix. While studying with lime fruit juice concentrate (squash) Wahab et al., (2018) found that the average TSS value was 53.00 ${ }^{\circ}$ Brix. The TSS of citron juice concentrate was lower than that of lime fruit juice concentrate.

Again $\mathrm{pH}$ and total acidity of the citron juice concentrate was found $3.42 \pm 0.03$ and $1.60 \pm 0.01 \%$, respectively. The $\mathrm{pH}$ and total acidity of lime fruit juice concentrate(squash) was 3.63 and 1.03 described by Wahab et al., (2018). Sharma et al., (2004) found that the titratable acidity of lemon juice concentrate was $5.40 \pm 0.08 \%$. The $\mathrm{pH}$ value of citron juice concentrate was lower to that of lime fruit juice concentrate and total acidity was moderately higher than that lime fruit juice concentrate but lower than lemon juice concentrate.

Table 1 Physico-chemical characteristics of citron juice concentrate

\begin{tabular}{lc}
\hline Parameters & Amount \\
\hline TSS ( ${ }^{\circ}$ Brix) & $45.00 \pm 0.20$ \\
pH & $3.42 \pm 0.03$ \\
Total acidity (\%) & $1.60 \pm 0.01$ \\
Vitamin C (mg/100 g) & $18.49 \pm 0.52$ \\
DPPH scavenging activity (\%) & $72.00 \pm 0.82$ \\
Total phenolic content (mgGAE/g) & $309.08 \pm 3.06$ \\
\hline
\end{tabular}

enolic content (moGAE/g)

$309.08+$

*Values are means \pm standard deviation $(n=3)$

\section{Bioactive compounds}

The bioactive compounds of juice concentrate such as ascorbic acid, tota phenolic contents and DPPH scavenging activity are presented in Table 1. Ascorbic acid is the most important heat sensitive antioxidant in citrus fruit juices (Babashahi-Kouhanestani, Salehi, Mazloomi, \& Almasi-Hashyani, 2014). Ascorbic acid is the natural antioxidants, which is easily degraded during heat treatment and if a compound contains higher ascorbic acid, its shows the higher antioxidant potentiality. The citron juice concentrates contained the ascorbic acid contents of $18.49 \pm 0.52 \mathrm{mg} / 100 \mathrm{~g}$. This ascorbic acid content of citron juice concentrate was much lower than the fresh ripe fruit juice of $C$. aurantium (24.90 $\mathrm{mg} / 100 \mathrm{~g}$ ) reported by Rekha et al., (2012). According to the previous study, the ascorbic acid content of ripe fruit juice of $C$. aurantium, $C$. sinensis, $C$. limon, Citrus macroptera, and $C$. reticulate were 24.90, 17.40, 10.60, 210.43 and 06.34 mg/100 g (M. Z. Islam et. al., 2015; Rekha et al., 2012). However, the ascorbic acid content of lime squash was about $23.28 \mathrm{mg} / 100 \mathrm{~g}$ that was higher than the citron juice concentrates (Wahab et al., 2018). Citrus is the important sources of major groups of antioxidants such as phenolic, flavonoid, ascorbic acid and vitamin E. The phenolics presents in fruit and vegetables have received considerable attentions due to their antioxidant activity. The phenolic content as total polyphenol was determined by Folin-Ciocalteu reagent and expressed equivalent to gallic acid. The citron juice concentrate contained the total phenolic content of $309.08 \pm 3.06 \mathrm{mgGAE} / \mathrm{g}$. The phenolic content was much higher than the Citrus unshiu (92.30 mgGAE/100 mL)(M. Z. Islam et al., 2017) and lower than the Citrus macroptera of $22.76 \mathrm{mgGAE} / \mathrm{g}$ (M. Z. Islam et. al., 2015) According to Costa et al., (2012) the total phenolic content of the mixed juice concentrate of Pomegranate, Grape, and Carrot was $133.00 \pm 0.0 \mathrm{mgGAE} / \mathrm{g}$. Irkin et al., (2015) found that total phenolic content of Grapefruit juice, Mandarin juice, Lemon juice, Orange juice were $657.65 \pm 69.20,636.73 \pm 68.74,579.41$ $\pm 91.14,523.44 \pm 87.20 \mathrm{mgGAE} / \mathrm{g}$. These reported results exhibited the lower total phenolic contents than the the citron juice concentrate.

The antioxidant activity of citron juice concentrate evaluated by DPPH scavenging activity. DPPH is a commercial oxidizing radical which can be reduced by samples antioxidants. During scavenging activity, DPPH reduced to pale yellow color from violet color because of the abstractions of a hydrogen atom from antioxidant compounds. Higher the DPPH reactions in the extract represent the most antioxidant potential. Similarly, a higher scavenging activity of samples means the higher reductions of DPPH (Blois, 1958). The DPPH scavenging activity of citron juice concentrate was found as $72.00 \pm 0.82 \%$. The higher DPPH results reported by Jeremić et al., (2012), who were mentioned that citron pulp exhibited the DPPH scavenging activity of $78.48 \%$. This may be due the effects of several factors i.e. different spices, environment and soil conditions or different maturity level. The commercial raspberry concentrated juice $(40 \%)$ contained DPPH scavenging activity of $61.90 \pm 1.70 \%$ (Costa et al., 2012) Smilarly Citrus unshiu also exhibited the lower DPPH schavenging activity $(62.13 \%)$ than the citron juice concentrate (M. Z. Islam et al., 2017).

\section{Degradation kinetics of ascorbic acid}

The degradation kinetics of ascorbic acid was calculated based on the ascorbic acid concentration in citron juice concentrate. Initially, the concentration of ascorbic acid was about $18.49 \mathrm{mg} / 100 \mathrm{~g}$. After one week of the storage, the ascorbic acid content of the juice concentrates was decreased to about 15.78 , 14.23 and $13.2 \mathrm{mg} / 100 \mathrm{~g}$ at $10^{\circ} \mathrm{C}, 25^{\circ} \mathrm{C}$ and $40^{\circ} \mathrm{C}$ respectively. Burdurlu et al. (2006) and Vikram, Ramesh, \& Prapulla (2005) stated that when the juice concentrate stored below $50{ }^{\circ} \mathrm{C}$ the degradation ascorbic acid follow first-order reaction kinetics. In the current study, the first-order reaction kinetics model was also used to study the degradation of ascorbic acid during the storage period. The first-order reaction kinetics " $k$ " along with standard error reported in Table 2. From the Table-2, the value of $\mathrm{R}^{2}$ were $0.93,0.93$ and 0.89 at $10{ }^{\circ} \mathrm{C}, 25{ }^{\circ} \mathrm{C}$ and $40{ }^{\circ} \mathrm{C}$ respectively, which indicated that the degradation follows the first-order reaction kinetics. Rate constant $\mathrm{k}$ prevailed with (1/week) unit. The rate of ascorbic acid degradation was higher in the initial weeks. According to Polydera et al., (2003) free oxygen present in the juice concentrate might cause it. All the values such as half life- $\left(t_{1 / 2}\right)$, rate constant $(k), \mathrm{R}^{2}$, decimal reduction time (D) and activation energy $\left(\mathrm{E}_{a}\right)$ were shown in Table 2 .

From Table-2, the rate constant values were $2.27 \pm 0.24,2.46 \pm 0.31$ and $2.56 \pm 0.341$ /week respectively in $10^{\circ} \mathrm{C}, 25^{\circ} \mathrm{C}$ and $40^{\circ} \mathrm{C}$ storage temperature With these results, we got that the degradation of ascorbic acid was higher at higher storage temperatures.

Here, $t_{1 / 2}$ means the half time which was decreased with the increase of temperature. This result was similar to the work of Burdurlu et al., (2006). The lower $D$ value at $40{ }^{\circ} \mathrm{C}$ indicates higher degradation of ascorbic acid. A similar result was obtained by Uddin, Hawlader, Ding, \& Mujumdar (2002) for the storage of guava juice at different temperatures. Activation energies were calculated based on Arrhenius plots for the degradation of ascorbic acid in the juice concentrate and shown in Fig. 4. The activation energy values were not comparable to literature values reported by several authors. Sapei \& Hwa (2014) stated that the activation energy of ascorbic acid degradation were estimated to be $1.65 \mathrm{kcal} / \mathrm{mol}$ and $1.90 \mathrm{kcal} / \mathrm{mol}$ for the fresh strawberry juices prepared without and with sugar, respectively. Here, activation energy was quite lower. Higher degradation of ascorbic acid at $40{ }^{\circ} \mathrm{C}$ temperature indicated that the degradation of ascorbic acid is more dependent on temperature and less dependent on sample other characters. Tiwari et al., (2009) also described orange juice ascorbic acid content decreased higher because of high storage temperature which was similar to the present study.

Table 2 Activation energy, half-life, rate constant and decimal reduction time for

\begin{tabular}{|c|c|c|c|c|c|}
\hline \multirow{2}{*}{$\begin{array}{l}\text { Storage } \\
\text { temperature } \\
{ }^{\circ} \mathrm{C}\end{array}$} & \multicolumn{4}{|c|}{$\begin{array}{c}\text { Time of half destruction, D-value and } \\
\text { determination coefficients of first-order } \\
\text { reaction kinetics }\end{array}$} & \multirow{2}{*}{$\begin{array}{c}\text { Activation } \\
\text { energy } \\
\mathbf{E}_{\mathrm{a}} \\
(\mathbf{k J} / \mathbf{m o l})\end{array}$} \\
\hline & $\mathrm{t}_{1 / 2}$ (week) & $\mathrm{k}(1 /$ week $)$ & $\mathrm{R}^{2}$ & $\mathrm{D}$ (week) & \\
\hline 10 & $\begin{array}{c}0.31 \pm \\
0.03^{\mathrm{a}}\end{array}$ & $\begin{array}{c}2.27 \pm \\
0.24^{\mathrm{a}}\end{array}$ & 0.93 & $\begin{array}{l}1.02 \pm \\
0.11^{\mathrm{a}}\end{array}$ & \\
\hline 25 & $\begin{array}{c}0.28 \pm \\
0.04^{\mathrm{a}}\end{array}$ & $\begin{array}{c}2.46 \pm \\
0.31^{\mathrm{a}}\end{array}$ & 0.93 & $\begin{array}{c}0.95 \pm \\
0.12^{\mathrm{a}}\end{array}$ & $2.95 \pm 0.01$ \\
\hline 40 & $\begin{array}{c}0.27 \pm \\
0.04^{\mathrm{a}}\end{array}$ & $\begin{array}{c}2.56 \pm \\
0.34^{\mathrm{a}} \\
\end{array}$ & 0.89 & $\begin{array}{c}0.91 \pm \\
0.12^{\mathrm{a}}\end{array}$ & \\
\hline
\end{tabular}
ascorbic acid degradation

*Values are means standard deviation $(n=3)$. Values in a column with different letter superscripts differ significantly at $p \leq 0.05$. 


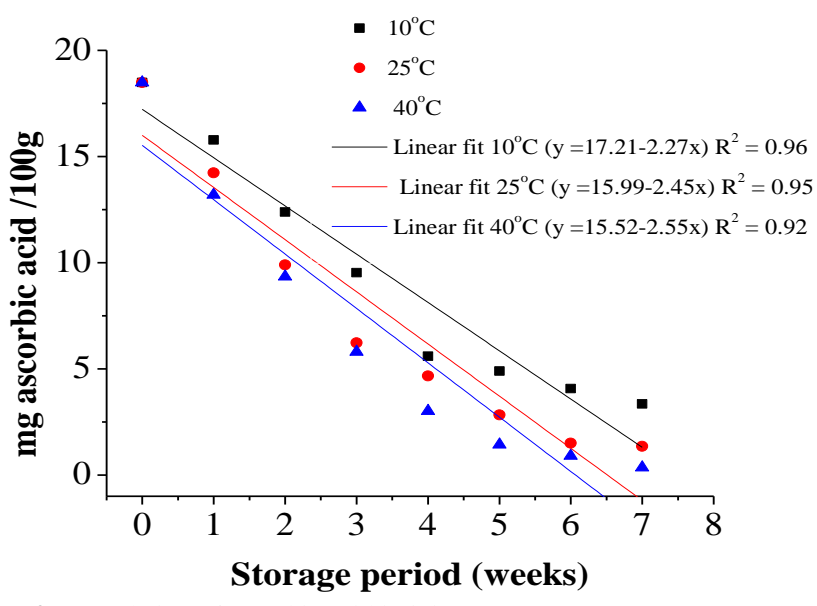

Figure 3 Degradation of ascorbic acid in juice concentrate

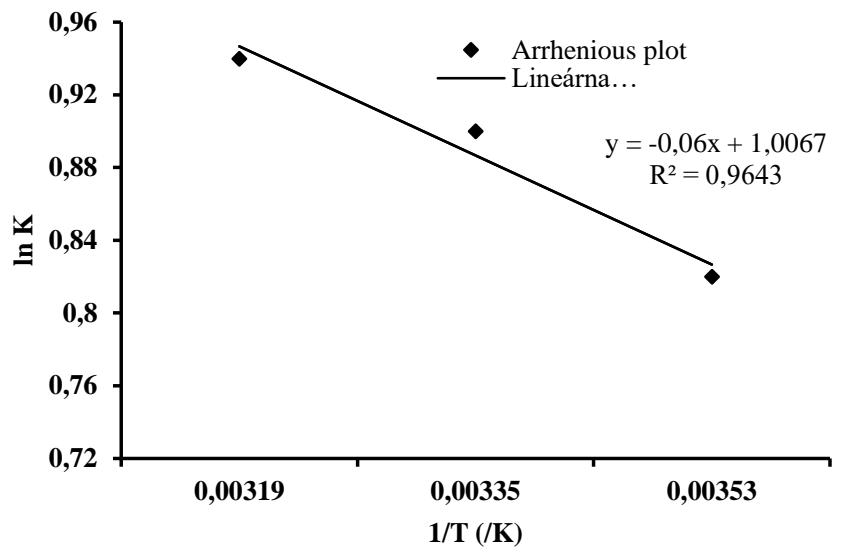

Figure 4 Arrhenius plot for ascorbic acid degradation for citron juice concentrate

\section{Changes in antioxidant activity}

The antioxidant activity of the juice concentrate was measured by using DPPH radical scavenging method. After one week of the storage, the DPPH scavenging activity was measured and found $65.76 \pm 4.39,60.35 \pm 5.00$ and $56.29 \pm 5.14 \%$ scavenging activity at three storage temperature $10{ }^{\circ} \mathrm{C}, 25{ }^{\circ} \mathrm{C}$ and $40{ }^{\circ} \mathrm{C}$ respectively. During storage period, the antioxidant activity was in descending order. The relationship among antioxidant activity, storage temperature and storage time were shown in the Fig. 5. With the increase of storage temperature the DPPH scavenging activity of the juice concentrates were decreased. Along with storage temperature, longer storage time also decreased DPPH scavenging activity of the juice concentrates. At $12^{\text {th }}$ week of the study, the values of DPPH scavenging activity at $10{ }^{\circ} \mathrm{C}, 25^{\circ} \mathrm{C}$ and $40{ }^{\circ} \mathrm{C}$ storage temperature were $32.15 \pm$ $0.95,30.86 \pm 0.31$ and $25.35 \pm 0.50 \%$ respectively. The reduction percentage of the antioxidant activity was higher at $40{ }^{\circ} \mathrm{C}$ storage temperature and it was $64.79 \%$ whereas at $10{ }^{\circ} \mathrm{C}$ storage temperature, it was $55.35 \%$. Kim et al., (2018), also found the antioxidant activity was decreased with higher storage temperature and longer storage time while studying with the kiwi puree. That's why storage temperature of citron juice concentrate should be lowered to avoid loss of antioxidant activity.

\section{$=10^{\circ} \mathrm{C} \quad 25^{\circ} \mathrm{C} \quad 40^{\circ} \mathrm{C}$}

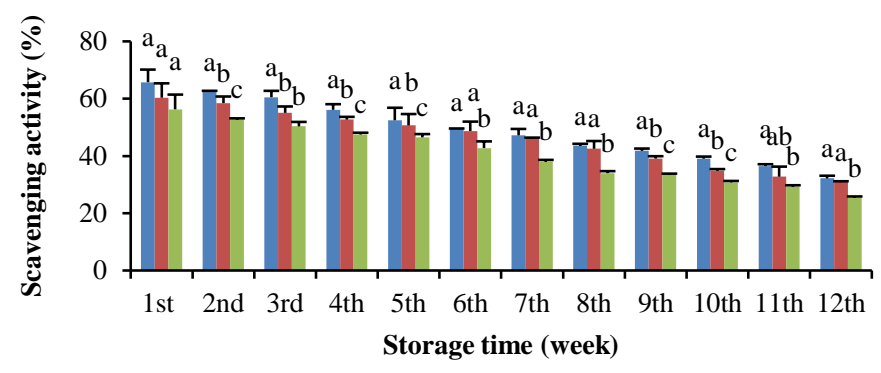

Figure 5 Changes in DPPH scavenging activity during storage at different temperature for juice concentrate

\section{Changes in total phenolic content}

The total phenolic content of the juice concentrate stored at three different storage temperatures was measured every week throughout the storage period. The relationship among total phenolic content, storage temperature and storage time were shown in Fig. 6. The total phenolic content of the juice concentrate after the first week was found to be $267.42 \pm 2.57,272.25 \pm 3.28$ and $285.25 \pm$ $3.06 \mathrm{mgGAE} / \mathrm{g}$ at $10{ }^{\circ} \mathrm{C}, 25^{\circ} \mathrm{C}$ and $40{ }^{\circ} \mathrm{C}$ temperature. Total phenolic conten was gradually reduced at the first stage of storage, but it began to increase at each storage temperature after third weeks. Finally, at $12^{\text {th }}$ week of the storage period the total phenolic content of the juice concentrate were $540.04 \pm 2.75,652.42 \pm$ 2.02 and $685.58 \pm 3.51 \mathrm{mgGAE} / \mathrm{g}$ at $10{ }^{\circ} \mathrm{C}, 25^{\circ} \mathrm{C}$ and $40{ }^{\circ} \mathrm{C}$ storage temperature respectively. Here the total phenolic content of the citron juice concentrate was increased with storage time and temperature. This phenomenon may be because higher temperature conditions trigger Maillard reactions producing Maillard products, which can act as antioxidants and can enhance their activity at the beginning of storage (Nicoli, Anese, Parpinel, Franceschi, \& Lerici, 1997). However, Kim et al., (2018) described that total phenolic content was decreased with the increase of storage temperature and time. The variation in the present study may occur due to the non-enzymatic browning reactions which result in the increment of polyphenol content in the juice concentrate. It is necessary to control enzymatic and non-enzymatic reaction to limit the total phenolic content in the juice concentrate during processing and storage period.

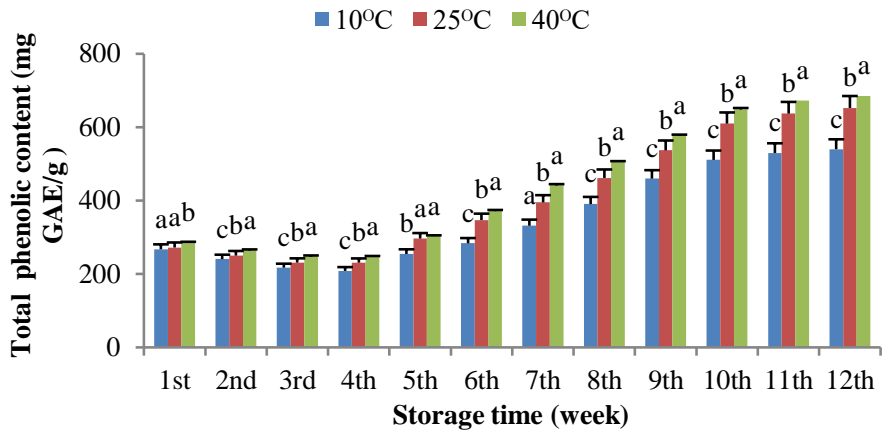

Figure 6 Changes in total phenolic content during storage at different temperature for juice concentrate

\section{CONCLUSION}

The present study concluded that Citron juice concentrate exhibited the higher greater amount of ascorbic acid, total phenolic compounds than than the citrus fruit. Degradation kinetics of ascorbic acid content of citron juice concentrate at each and every storage temperature was followed first-order reaction. The present study showed that at a higher temperature $\left(40{ }^{\circ} \mathrm{C}\right)$ rate of degradation of ascorbic acid was higher. The degradation of antioxidant activity of the juice concentrate was quite low at lower storage temperature. However, the change of the total phenolic contents was quite different. It was increased with storage time and temperature. Therefore, the findings of the current study suggest that the value added product could be processed from indigenous citron juice with higher functional compounds. Upscaling and validation are needed for the developed technologies before recommendation and transfer to the entrepreneurs for commercial production and marketing.

Acknowledgments: Authors acknowledge the Department of Food Engineering and Tea Technology for providing facilities to carry out this research successfully.

\section{REFERENCES}

Arias, B. Á., \& Ramón-Laca, L. (2005). Pharmacological properties of citrus and their ancient and medieval uses in the Mediterranean region. Journal of Ethnopharmacology, 97(1), 89-95. https://doi.org/10.1016/j.jep.2004.10.019

Babashahi-Kouhanestani, M., Salehi, M., Mazloomi, S., \& Almasi-Hashyani, A (2014). Quantitative evaluation of vitamin C in industrial lemon juice by titration method. Journal of Biology and Today's World, 3(6), 139-141. https://doi.org/10.15412/J.JBTW.01030605

Blois, M. S. (1958). Antioxidant Determinations by the Use of a Stable Free Radical. Nature, 181(4617), 1199-1200. https://doi.org/10.1038/1811199a0 Brand-Williams, W., Cuvelier, M. E., \& Berset, C. (1995). Use of a free radical method to evaluate antioxidant activity. LWT - Food Science and Technology, 28(1), 25-30. https://doi.org/10.1016/S0023-6438(95)80008-5

Burdurlu, H. S., Koca, N., \& Karadeniz, F. (2006). Degradation of vitamin C in citrus juice concentrates during storage. Journal of Food Engineering, 74(2), 211-216. https://doi.org/10.1016/j.jfoodeng.2005.03.026

Chhikara, N., Kour, R., Jaglan, S., Gupta, P., Gat, Y., \& Panghal, A. (2018). Citrus medica: nutritional, phytochemical composition and health benefits - a review . Food \& Function. https://doi.org/10.1039/c7fo02035j 
Costa, A. S. G., Nunes, M. A., Almeida, I. M. C., Carvalho, M. R., Barroso, M. F., Alves, R. C., \& Oliveira, M. B. P. P. (2012). LWT - Food Science and Technology Teas, dietary supplements and fruit juices: A comparative study regarding antioxidant activity and bioactive compounds. LWT - Food Science and Technology, 49(2), 324-328. https://doi.org/10.1016/j.lwt.2012.02.030

Hamdan, D., El-Readi, M. Z., Tahrani, A., Herrmann, F., Kaufmann, D., Farrag, N., ... Wink, M. (2011). Chemical composition and biological activity of Citrus jambhiri Lush. Food Chemistry, 127(2), 394-403. https://doi.org/10.1016/j.foodchem.2010.12.129

Irkin, R., Dogan, S., Degirmencioglu, N., Diken, M., \& Guldas, M. (2015) Phenolic content, antioxidant activities and stimulatory roles of citrus fruits on some lactic acid bacteria. Archives of Biological Sciences, 67(4), 1313-1321. https://doi.org/10.2298/ABS140909108I

Islam, M. Z. . b, Hoque, M. M. ., Asif-Ul-Alam, S. M. ., \& Monalisa, K. . (2015) Chemical composition, antioxidant capacities and storage stability of Citrus macroptera and Garcinia pedunculata fruits. Emirates Journal of Food and Agriculture, 27(3), 275-282. https://doi.org/10.9755/ejfa.v27i3.18624

Islam, M. Z., Kitamura, Y., Kokawa, M., Monalisa, K., Tsai, F.-H., \& Miyamura, S. (2017). Effects of micro wet milling and vacuum spray drying on the physicochemical and antioxidant properties of orange (Citrus unshiu) juice with pulp powder. Food and Bioproducts Processing, 101, 132-144. https://doi.org/10.1016/j.fbp.2016.11.002

Jeremić, S. R., Šehović, S. F., Manojlović, N. T., \& Marković, Z. S. (2012). Antioxidant and free radical scavenging activity of purpurin. Monatshefte Für Chemie - Chemical Monthly, 143(3), 427-435. https://doi.org/10.1007/s00706011-0695-z

Kalt, W., Forney, C. F., Martin, a, \& Prior, R. L. (1999). Antioxidant Capacity, Vitamin C, Phenolics, and Anthocyanins After. Journal of Agricultural and Food Chemistry, 47(11), 4638-4644. https://doi.org/10.1021/jf990266t

Kim, A. N., Kim, H. J., Chun, J., Heo, H. J., Kerr, W. L., \& Choi, S. G. (2018) Degradation kinetics of phenolic content and antioxidant activity of hardy kiwifruit (Actinidia arguta) puree at different storage temperatures. LWT - Food Science and Technology, 89(November), 535-541. https://doi.org/10.1016/j.1wt.2017.11.036

Klein, J., \& Klein, J. D. (2014). Medicinal and Aromatic Plants of the Middle East. 2(August 2014). https://doi.org/10.1007/978-94-017-9276-9

Luro, F., Venturini, N., Costantino, G., Paolini, J., Ollitrault, P., \& Costa, J. (2012). Genetic and chemical diversity of citron (Citrus medica L.) based on nuclear and cytoplasmic markers and leaf essential oil composition. Phytochemistry, 77, 186-196. https://doi.org/10.1016/j.phytochem.2011.12.013

Monalisa, K., Bhuiyan, J., Islam, M., \& Sayem, A. (2019). Boiling-induced changes on physicochemical, bioactive compounds, color, and texture properties of pumpkin (Cucurbita maxima). Food Science and Technology International, 108201321989440. https://doi.org/10.1177/1082013219894402

Monalisa, K., \& Islam, J. A. B. M. Z. (2020). Bioactive compounds and in vitro antioxidant activity assessment of GM Bt eggplant-III ( Noyantara ) and stability upon boiling. Journal of Food Measurement and Characterization, 14(3), 13831390. https://doi.org/10.1007/s11694-020-00388-2

Nicoli, M. C., Anese, M., Parpinel, M. T., Franceschi, S., \& Lerici, C. R. (1997) Loss and/or formation of antioxidants during food processing and storage Cancer Letters, 114(1-2), 71-74. https://doi.org/10.1016/S0304-3835(97)046284

Polydera, A. C., Stoforos, N. G., \& Taoukis, P. S. (2003). Comparative shelf life study and vitamin $\mathrm{C}$ loss kinetics in pasteurised and high pressure processed reconstituted orange juice. Journal of Food Engineering, 60(1), 21-29. https://doi.org/10.1016/S0260-8774(03)00006-2

Rekha, C., Poornima, G., Manasa, M., Abhipsa, V., Devi, J. P., Kumar, H. T. V., \& Kekuda, T. R. P. (2012). Ascorbic Acid, Total Phenol Content and Antioxidant Activity of Fresh Juices of Four Ripe and Unripe Citrus Fruits. Chemical Science Transactions, 1(2), 303-310. https://doi.org/10.7598/cst2012.182

Sapei, L., \& Hwa, L. (2014). Study on the Kinetics of Vitamin C Degradation in Fresh Strawberry Juices. Procedia Chemistry, 9, 62-68. https://doi.org/10.1016/j.proche.2014.05.008

Singh, V. K., Kumar, R., \& Gogoi, G. (2015). Formulation and acceptability studies of squash prepared from indigenous Assam lemon. IOSR Journal of Environmental Science Ver. II, 9(10), 2319-2399. https://doi.org/10.9790/2402091026265

Tiwari, B. K., O’ Donnell, C. P., Muthukumarappan, K., \& Cullen, P. J. (2009). Ascorbic acid degradation kinetics of sonicated orange juice during storage and comparison with thermally pasteurised juice. LWT - Food Science and Technology, 42(3), 700-704. https://doi.org/10.1016/j.1wt.2008.10.009

Uddin, M. S., Hawlader, M. N. A., Ding, L., \& Mujumdar, A. S. (2002).

Degradation of ascorbic acid in dried guava during storage. Journal of Food Engineering, 51(1), 21-26. https://doi.org/10.1016/S0260-8774(01)00031-0

Vijaya Kumar Reddy, C., Sreeramulu, D., \& Raghunath, M. (2010). Antioxidant activity of fresh and dry fruits commonly consumed in India. Food Research International, 43(1), 285-288. https://doi.org/10.1016/j.foodres.2009.10.006

Vikram, V. B., Ramesh, M. N., \& Prapulla, S. G. (2005). Thermal degradation kinetics of nutrients in orange juice heated by electromagnetic and conventional methods. Journal of Food Engineering, 69(1), 31-40. https://doi.org/10.1016/j.jfoodeng.2004.07.013

Wahab, H. (2018). Comparative study of five different squashes stored at room temperature. Pure and Applied Biology, 7(1), 33-41. https://doi.org/10.19045/bspab.2018.70005 